\title{
Molecular analysis of methicillin-resistant Staphylococcus aureus isolates from four teaching hospitals in Iran: the emergence of novel MRSA clones
}

Farzaneh Firoozeh ${ }^{1,2,3^{*}}$ D. Mitra Omidi ${ }^{i^{*}}$, Mahmood Saffari ${ }^{1}$, Hossein Sedaghat ${ }^{1}$ and Mohammad Zibaei ${ }^{4,5}$

\begin{abstract}
Background: The global spread of methicillin-resistant Staphylococcus aureus (MRSA) infections necessitates the use of validated methods for the identification and typing of this bacterium. This study aimed to determine the distribution of main molecular types of MRSA strain circulating among hospitalized patients in teaching hospitals in Isfahan and Kashan.

Methods: A total of 146 Staphylococcus aureus strains were isolated from patients in four teaching hospitals in Isfahan and Kashan during June 2017 to September 2018. The antimicrobial resistance patterns of Staphylococcus aureus strains were performed by disc diffusion method. The MRSA strains were identified phenotypically and confirmed by PCR assay. The prevalence of microbial surface components recognizing adhesive matrix molecules (MSCRAMMs) genes among MRSA strains was evaluated by multiplex PCR. The genotypes of MRSA strains were determined by multilocus sequence typing and SCCmec typing.

Results: Of 146 Staphylococcus aureus isolates, 24 (16.4\%) isolates were identified as MRSA strains. According to antimicrobial susceptibility testing the highest resistance rates were seen for tetracycline, erythromycin, ciprofloxacin and gentamicin. All of Staphylococcus aureus isolates were susceptible to vancomycin whereas 3 (2.1\%) isolates were resistant to linezolid. Three different SCCmec types were obtained among MRSA strains including 16 (66.7\%) SCCmec type V, 3 (12.5\%) SCCmec type III and 5 (20.8\%) SCCmec type II. Of 24 MRSA isolates 20 (83.3\%) carried MSCRAMMs genes including eno (70.8\%), fib (54.1\%), cna (25.0\%), fnbB (16.6\%), ebps 5 (20.8\%), and the fnbA, bbp and CIfA genes were not detected in any MRSA isolate. MLST analysis revealed 11 sequence types among MRSA isolates as follows: ST239, ST291, ST22, ST861, ST889, ST8, ST59, ST343, ST772, ST6 and ST1465. Also seven MLST-based clonal complexes (CCs) were identified among MRSA strains including: CC8, CC7, CC398, CC59, CC22, CC1 and CC5.

*Correspondence: ffiroozeh@ut.ac.ir; omidi.mitra688@gmail.com

'Department of Microbiology, School of Medicine, Kashan University of Medical Sciences, Kashan, Iran

Full list of author information is available at the end of the article

(c) The Author(s). 2020 Open Access This article is licensed under a Creative Commons Attribution 4.0 International License, which permits use, sharing, adaptation, distribution and reproduction in any medium or format, as long as you give appropriate credit to the original author(s) and the source, provide a link to the Creative Commons licence, and indicate if changes were made. The images or other third party material in this article are included in the article's Creative Commons licence, unless indicated otherwise in a credit line to the material. If material is not included in the article's Creative Commons licence and your intended use is not permitted by statutory regulation or exceeds the permitted use, you will need to obtain permission directly from the copyright holder. To view a copy of this licence, visit http://creativecommons.org/licenses/by/4.0/ The Creative Commons Public Domain Dedication waiver (http://creativecommons.org/publicdomain/zero/1.0/) applies to the data made available in this article, unless otherwise stated in a credit line to the data. 


\begin{abstract}
(Continued from previous page)
Conclusions: A relatively high diversity was found in MRSA genotypes in Kashan and Isfahan hospitals, and seven clonal complexes were identified. Pandemic MRSA clones including CC8 and CC22 were the most prevalent clones and the novel ST types including ST1465, ST861, ST 889 and ST772 are reported for the first time in Iran in the present study. In addition the high prevalence of MSCRAMMs genes in MRSA isolates demonstrates the high potential of these strains for pathogenicity.
\end{abstract}

Keywords: MRSA, MLST, SCCmec typing, MSCRAMMs, Genotyping

\section{Background}

Staphylococcus aureus (S. aureus) is one of the most important human pathogen that causes a wide range of infections [1]. An important part of $S$. aureus success in developing the disease depends on its ability to bind to host cells and extracellular matrix proteins $[2,3]$. Adherence to host cells and proteins is mediated by adhesive molecules which are called microbial surface components recognizing adhesive matrix molecules (MSCR AMMs) [4, 5]. These components are attached covalently to peptidoglycan by sortase enzymes $[2,6]$. The bacterium is also highly regarded for its ability to obtain resistance to diverse antibiotics [2]. The emergence of methicillin-resistant S. aureus (MRSA) strains is an increasing public health challenge associated with high mortality and morbidity [7]. MRSA strain generates a low-affinity penicillin binding protein (PBP2a) that is responsible for the resistance to beta-lactam antibiotics [7]. PBP2a is encoded by mecA gene, carried by the Staphylococcal cassette chromosome mec (SCCmec) which as a large mobile genetic element is integrated to a region of the chromosome of MRSA [8]. In order to carry out epidemiological studies of MRSA strains several typing methods are available $[9,10]$. Staphylococcal cassette chromosome mec (SCCmec) typing is a trustful typing method especially to make difference between hospital-acquired MRSA (HA-MRSA) and community-associated MRSA (CA-MRSA) [10]. Till now 13 SCCmec types have been documented and majority of MRSA strains which isolate from HA-MRSA strains bear SCCmec types I, II, and III [8]. Sequencing based typing methods such as multilocus sequence typing (MLST) have recently been introduced and received a lot of attention [10]. MLST typing is a reliable method to study genetic macro- variation in large populations based on specification of allelic profile of fragments of seven house-keeping genes [10-13].. There are some reports of molecular analysis and typing of MRSA strains from all over the world, although there is limited data regarding major MRSA clones circulating in our region. In the present study we used two reliable typing methods including MLST and SCCmec typing to reveal and compare the common genotypes of MRSA isolates circulating in four teaching hospitals in Isfahan and Kashan. Also the prevalence of virulence and MSCR AMMs genes among these MRSA strains was evaluated.

\section{Methods}

Bacterial strains and identification

A total of $146 \mathrm{~S}$. aureus strains were isolated from clinical samples of patients admitted to teaching hospitals in Isfahan $(n=96)$ and Kashan $(n=50)$ during June 2017 to September 2018. Informed consent from all patients was obtained by survey questionnaire. The samples were cultured on blood agar (Merck, Germany), and plates were incubated at $37^{\circ} \mathrm{C}$ for $24 \mathrm{~h}$. S. aureus strains were identified by conventional microbiological methods including gram staining, and biochemical tests such as catalase, coagulase, mannitol fermentation, and DNase tests [14].

\section{Antimicrobial resistance patterns and phenotypic isolation of MRSA strains}

The antimicrobial resistance patterns of $S$. aureus strains were performed by agar disc diffusion method according to the Clinical and Laboratory Standards Institute (CLSI) [15]. The antibiotic discs were prepared from MAST Company (MAST, UK) as follows: tetracycline (T; $30 \mu \mathrm{g})$, erythromycin (E; $15 \mu \mathrm{g})$, clindamycin (CD; $2 \mu \mathrm{g}$ ), cefazolin (CZ; $30 \mu \mathrm{g})$, cefoxitin (FOX; $30 \mu \mathrm{g}$ ), linezolid (LZD; $30 \mu \mathrm{g}$ ), ciprofloxacin (CIP; $5 \mu \mathrm{g}$ ), gentamicin (GEN; $10 \mu \mathrm{g}$ ), and trimethoprim sulfamethoxazole (TS; $25 \mu \mathrm{g})$. MICs for vancomycin were determined by broth microdilution methodology recommended by the CLSI [16]. The S. aureus strains ATCC 25923 and ATCC 29213 were used as quality control strains for agar disk diffusion and broth microdilution, respectively. For confirmation of MRSA strains, cefoxitin $(30 \mu \mathrm{g})$ and oxacillin $(1 \mu \mathrm{g})$ disks (Mast, UK) and disc diffusion method was performed on Mueller- Hinton agar (Merck, Germany) in accordance with the CLSI [16].

\section{DNA extraction and detection of femA and mecA genes}

DNA extraction was performed by a standard phenolchloroform method as previously described [1]. All phenotypically isolated MRSA strains were confirmed by 
polymerase chain amplification (PCR), for this purpose, femA and mecA genes were amplified. For amplification of mecA gene forward and reveres primers were used to detect a $268 \mathrm{bp}$ fragment (Table 1) [19]. The PCR thermocycling program was: initial denaturation step at $97^{\circ} \mathrm{C}$ for $6 \mathrm{~min}$; followed by 30 cycles of $92^{\circ} \mathrm{C}$ for $30 \mathrm{~s}$, $55^{\circ} \mathrm{C}$ for $30 \mathrm{~s}$ and $72^{\circ} \mathrm{C}$ for $45 \mathrm{~s}$, which finally ended with final extension step at $72{ }^{\circ} \mathrm{C}$ for ten min [20]. The
S. aureus strain COL which carry mecA gene was used as positive control.

The $450 \mathrm{bp}$ amplicon of $f e m A$ gene was detected by PCR assays using specific primers and thermocycler (Eppendorf master cycler, MA) (Table 1) with following run program: initial denaturation at $94{ }^{\circ} \mathrm{C}$ for $5 \mathrm{~min}, 40$ cycles of $94{ }^{\circ} \mathrm{C}$ for $30 \mathrm{~s}, 55^{\circ} \mathrm{C}$ for $40 \mathrm{~s}$ and $72{ }^{\circ} \mathrm{C}$ for $50 \mathrm{~s}$ and final extension at $72^{\circ} \mathrm{C}$ for $10 \mathrm{~min}$ [17]. The PCR

Table 1 The primers of genes used in this study

\begin{tabular}{|c|c|c|c|c|}
\hline Target & Gene & Primer sequence $\left(5^{\prime}-3^{\prime}\right)$ & Size of product (bp) & Reference \\
\hline femA & femA & $\begin{array}{l}\text { F: TGCTATCCACCCTCAAACAGG } \\
\text { R: AACGTTGTAACCACCCCAAGA }\end{array}$ & 450 & [13] \\
\hline mecA & mecA & $\begin{array}{l}\text { F: TGCTATCCACCCTCAAACAGG } \\
\text { R: AACGTTGTAACCACCCCAAGA }\end{array}$ & 286 & [17] \\
\hline \multirow[t]{4}{*}{ sccmec } & ccrA2 & $\begin{array}{l}\text { F: TAAAGGCATCAATGCACAAACACT } \\
\text { R: AGCTCAAAAGCAAGCAATAGAAT }\end{array}$ & 937 & [18] \\
\hline & $\operatorname{ccrC}$ & $\begin{array}{l}\text { F: CCTTATAGGACTGGATTATTCAAAATAT } \\
\text { R:CGTCTATTACAAGATGTTAAGGATAAT }\end{array}$ & 518 & \\
\hline & $1 S 1272$ & $\begin{array}{l}\text { F: GCCACTCATAACATATGGAA } \\
\text { R: CATCCGAGTGAAACCCAAA }\end{array}$ & 415 & \\
\hline & mecA-IS431 & $\begin{array}{l}\text { F: TATACCAAACCCGACAACTAC } \\
\text { R: CGGCTACAGTGATAACATCC }\end{array}$ & 359 & \\
\hline \multirow[t]{8}{*}{ MSCRAMMs genes } & $b b p$ & $\begin{array}{l}\text { F: AACTACATCTAGTACTCAACAACAG } \\
\text { R: ATGTGCTTGAATAACACCATCATCT }\end{array}$ & 575 & [5] \\
\hline & cna & $\begin{array}{l}\text { F: GTCAAGCAGTTATTAACACCAGAC } \\
\text { R: AATCAGTAATTGCACTITGTCCACTG }\end{array}$ & 423 & \\
\hline & eno & $\begin{array}{l}\text { F: ACGTGCAGCAGCTGACT } \\
\text { R: CAACAGCATYCTTCAGTACCTTC }\end{array}$ & 302 & \\
\hline & ebps & $\begin{array}{l}\text { F: CATCCAGAACCAATCGAAGAC } \\
\text { R:CTTAACAGTTACATCATCATGTTIATCTITG }\end{array}$ & 186 & \\
\hline & $f n b A$ & $\begin{array}{l}\text { F: GTGAAGTTITAGAAGGTGGAAAGATTAG } \\
\text { R: GCTCTTGTAAGACCATIITCTTCAC }\end{array}$ & 643 & \\
\hline & $f n b B$ & $\begin{array}{l}\text { F: GTAACAGCTAATGGTCGAATTGATACT } \\
\text { R: CAAGTTCGATAGGAGTACTATGTTC }\end{array}$ & 524 & \\
\hline & fib & $\begin{array}{l}\text { F: CTACAACTACAATTGCCGTCAACAG } \\
\text { R: GCTCTTGTAAGACCATITCTTCAC }\end{array}$ & 404 & \\
\hline & clfA & $\begin{array}{l}\text { F: ATTGGCGTGGCTTCAGTGCT } \\
\text { R: CGTTCTTCCGTAGTTGCATTTG }\end{array}$ & 292 & \\
\hline \multirow[t]{8}{*}{ Housekeeping genes } & $\operatorname{arc}$ & $\begin{array}{l}\text { up: TTGATTCACCAGCGCGTATTGTC } \\
\text { dn: AGGTATCTGCTTCAATCAGCG }\end{array}$ & 456 & www.pubmlst.com \\
\hline & aro & $\begin{array}{l}\text { up: ATCGGAAATCCTATTTCACATTC } \\
\text { dn: GGTGTTGTATTAATAACGATATC }\end{array}$ & 456 & \\
\hline & $g / p$ & $\begin{array}{l}\text { up: CTAGGAACTGCAATCTTAATCC } \\
\text { dn: TGGTAAAATCGCATGTCCAATTC }\end{array}$ & 465 & \\
\hline & $g m k$ & up: ATCGTTTTATCGGGACCATC & 429 & \\
\hline & & dn: TCATTAACTACAACGTAATCGTA & & \\
\hline & pta & $\begin{array}{l}\text { up: GTTAAAATCGTATTACCTGAAGG } \\
\text { dn: GACCCTIITGTTGAAAAGCTTAA }\end{array}$ & 474 & \\
\hline & tpi & $\begin{array}{l}\text { up: TCGTTCATTCTGAACGTCGTGAA } \\
\text { dn: TTTGACCTTCTAACAATTGTAC }\end{array}$ & 402 & \\
\hline & ygi & $\begin{array}{l}\text { up: CAGCATACAGGACACCTATTGGC } \\
\text { dn: CGTTGAGGAATCGATACTGGAAC }\end{array}$ & 516 & \\
\hline
\end{tabular}


products were visualized after electrophoresis on $1 \%$ agarose gel under UV transilluminator (Bio-Rad, UK).

\section{Multiplex PCR for SCCmec typing}

Five main SCCmec types of MRSA srtains were determined using multiplex PCR method with specific primers according to method previously presented by Boye et al. [18, 21]. For this purpose PCR reactions were performed in a final volume of $25 \mu \mathrm{L}$. Amplification was done with initial denaturation step $\left(94^{\circ} \mathrm{C}, 4 \mathrm{~min}\right), 30$ cycles of denaturation $\left(94^{\circ} \mathrm{C}, 30 \mathrm{~s}\right)$, annealing $\left(55^{\circ} \mathrm{C}, 30\right.$ s), extension $\left(72{ }^{\circ} \mathrm{C}, 60 \mathrm{~s}\right)$, and a final extension at $72^{\circ} \mathrm{C}$ for $4 \mathrm{~min}$, (Table 1 ).

\section{Identification of adhesive matrix molecules MSCRAMMs genes}

The PCR amplification of MSCRAMMs genes were performed according to Tristan et al. [6] PCR1 was performed to amplify $b b p$, $c n a, e b p S$, and eno genes and PCR2 was applied to amplify $f n b A, f n b B$, fib, and $c l f A$, genes. The thermal cycling condition of multiplex PCR included an initial denaturation step $\left(5 \mathrm{~min}\right.$ at $\left.94{ }^{\circ} \mathrm{C}\right)$ followed by 25 cycles of denaturation $\left(1 \mathrm{~min}\right.$ at $\left.94^{\circ} \mathrm{C}\right)$, annealing $\left(1 \mathrm{~min}\right.$ at $\left.55^{\circ} \mathrm{C}\right)$, and extension $(1 \mathrm{~min}$ at $72^{\circ} \mathrm{C}$ ). The reaction was terminated with a $10 \mathrm{~min}$ incubation step at $72{ }^{\circ} \mathrm{C}$ [7]. (Table 1 ).

\section{Multilocus sequence typing (MLST)}

The MLST types of 24 identified MRSA strains were determined. Identification of internal fragments of 7 housekeeping genes was performed by PCR amplification according to MLST websites (www.mlst.net) [22]. (Table 1 ). The final volume of PCR mixture was $25 \mu \mathrm{L}$ with thermal program including: $95^{\circ} \mathrm{C}$ for $15 \mathrm{~min}$ followed by 30 cycles of $\left(95^{\circ} \mathrm{C}\right.$ for $\left.1 \mathrm{~min}\right),\left(51^{\circ} \mathrm{C}\right.$ for $\left.1 \mathrm{~min}\right)$, and $\left(72{ }^{\circ} \mathrm{C}\right.$ for $1 \mathrm{~min}$ ) and finally $72^{\circ} \mathrm{C}$ for $5 \mathrm{~min}$ [22].

\section{Data analysis}

Data were analyzed using SPSS software Version 19.0. We were used Chi square or Fisher's exact tests to determine the significance of the differences. A difference was considered statistically significant if the $P$-value was less than 0.05 .

\section{Results}

This study was performed on 146 clinical samples $[$ Female $=82(56.2 \%)$; Male $=64(43.8 \%)]$ collected from teaching hospitals in Isfahan (Imam Musa Kazem, Amin and Al-Zahra Hospitals) and Kashan (Shahid Beheshti Hospital). Clinical samples were collected of burn wound 56 (38.4\%), eye infection 49 (33.6\%), respiratory infections $11(7.5 \%)$, trauma $6(4.1 \%)$, diabetic wound 5 (3.4\%), brain abscess 5 (3.4\%), blood 3(2\%), urine 9(6.2), and other infections 2 (1.4\%). There was no significant difference between MRSA and MSSA isolates in terms of age groups, gender and clinical specimens $(P>0.05)$, although a significant correlation was seen between the methicillin resistance and teaching hospitals from which clinical samples has been obtained $(P=0.001)$.

The results of PCR amplification of $m e c A$ gene showed among 146 studied S. aureus isolates 24 (16.4\%) isolates identified as MRSA strains.

According to results obtained from antibiotic susceptibility testing, resistance rates to tetracycline 19 (79.2\%), erythromycin $17(70.8 \%)$, ciprofloxacin 16 (66.7\%), and gentamicin 15 (62.5\%) was high among MRSA strains and all $S$. aureus isolates were sensitive to vancomycin (MIC $<2 \mu \mathrm{g} / \mathrm{mL}$ ) (Table 2). The MRSA strains were significantly more resistant to the antibiotics studied in comparison to MSSA strains $(P<0.05)$, and there was a significant correlation between multiple-drug resistance and MRSA isolation $(P=0.001)$.

\section{SCCmec typing}

Three different SCCmec types were obtained among MRSA strains including 16 (66.7\%) SCCmec type V, 3 (12.5\%) SCCmec type III and, 5 (20.8\%) SCCmec type II (Table 3).

\section{Identification of MSCRAMMs genes}

Of 24 MRSA isolates, 20 (83.3\%) carried MSCRAMMs genes and in $4(16.6 \%)$ of which, none of the MSCR AMMs genes studied were isolated. The prevalence of eno, fib, cna, fnbB, ebps, genes in MRSA isolates were 17 (70.8\%), 13 (54.1\%), 6 (25.0\%), 4 (16.6\%) and 5 (20.8\%), respectively. Six, 2, and 4 isolates carried 4,3 and 2 bands related to MSCRAMMs determinants respectively and the $f n b A, b b p$ and $c l f A$ genes were not detected in any MRSA isolate (Table 3 ).

In statistical analyses a significant correlation was obtained between MRSA strains and eno, cna and fib genes, $(P<0.001)$. In statistical analyses a significant

Table 2 Antimicrobial resistance among MRSA and MSSA strains

\begin{tabular}{llll}
\hline Antibiotic (\%) & MRSA (\%) & MSSA (\%) & Total (\%) \\
& $N=24$ & $N=122$ & $N=146$ \\
\hline Tetracycline & $19(79.2)$ & $31(25.4)$ & $50(34.2)$ \\
Erythromycin & $17(70.8)$ & $28(22.9)$ & $45(30.8)$ \\
Ciprofloxacin & $16(66.7)$ & $17(13.9)$ & $33(22.6)$ \\
Gentamicin & $15(62.5)$ & $9(7.3)$ & $24(16.4)$ \\
Clindamycin & $14(58.3)$ & $8(6.6)$ & $22(15.1)$ \\
Cefazolin & $13(54.2)$ & $1(1)$ & $14(9.6)$ \\
Linezolid & $1(4.2)$ & $2(1.6)$ & $3(2.1)$ \\
Trimethoprim Sulfamethoxazole & $8(33.3)$ & $6(4.9)$ & $14(9.6)$ \\
\hline
\end{tabular}


Table 3 Characteristics of the MRSA isolates from clinical samples in different hospitals $(N=24)$

\begin{tabular}{|c|c|c|c|c|c|c|c|}
\hline Source & Hospital & Ward & Antibiotic resistance pattern & MSCRAMMs & SCCmec type & Clonal Complex & $\mathrm{ST}^{d}$ \\
\hline Blood & $\mathrm{SB}^{a}$ & Emergency & $\mathrm{T}^{*}, \mathrm{E}, \mathrm{CIP}, \mathrm{GEN}, \mathrm{CD}, \mathrm{CZ}, \mathrm{TS}, \mathrm{FOX}$ & eno, cna, fib, fnbB & $\|$ & 8 & 239 \\
\hline \multirow[t]{15}{*}{ Burn wound } & $\mathrm{IMK}^{\mathrm{b}}$ & Skin & T, E, CIP, GEN, CD, CZ, TS, FOX & eno, cna, fib, fnbB & III & 8 & 861 \\
\hline & IMK & Skin & $T, E, C I P, G E N, C D, C Z, F O X$ & eno, cna, fib & III & 7 & 239 \\
\hline & IMK & Skin & E, CIP, GEN, CZ, FOX & eno & V & 8 & 8 \\
\hline & IMK & Skin & T, CIP, LZD, FOX & $e n o, e b p, f i b, f n b B$ & V & 398 & 291 \\
\hline & IMK & Skin & T, E, CIP, GEN, CD, TS, FOX & eno, fib & V & 59 & 59 \\
\hline & IMK & Skin & FOX & eno, cna & V & 59 & 59 \\
\hline & IMK & Skin & T, FOX & - & $\|$ & 398 & 291 \\
\hline & IMK & Skin & T, FOX & - & $\|$ & 22 & 22 \\
\hline & IMK & Skin & $T, E, C I P, G E N, C D, C Z, F O X$ & eno, cna, ebp, fib & $\|$ & 8 & 239 \\
\hline & IMK & Skin & $\mathrm{T}, \mathrm{CZ}, \mathrm{TS}, \mathrm{FOX}$ & eno & V & 8 & 1465 \\
\hline & IMK & Skin & T, TS, FOX & eno & V & 22 & 22 \\
\hline & IMK & Skin & E, FOX & eno,cna, ebp, fib & V & 1 & 772 \\
\hline & IMK & Skin & T, E, CIP, GEN, CD, CZ, TS, FOX & eno & V & 22 & 22 \\
\hline & IMK & Skin & E, FOX & eno, ebp, fib & V & 5 & 6 \\
\hline & IMK & Skin & T, E, CIP, GEN, CD, CZ, TS, FOX & eno, fib & V & 8 & 1465 \\
\hline \multirow[t]{6}{*}{ Eye infection } & SB & Emergency & $T, E, C I P, G E N, C D, T S, F O X$ & eno & $\|$ & 8 & 889 \\
\hline & Amin & Emergency & $\mathrm{T}, \mathrm{E}, \mathrm{CIP}, \mathrm{GEN}, \mathrm{CD}, \mathrm{CZ}, \mathrm{FOX}$ & fib & III & 8 & 239 \\
\hline & Amin & Emergency & $T, E, C I P, G E N, C D, C Z, F O X$ & - & V & 8 & 1465 \\
\hline & Amin & Emergency & $\mathrm{T}, \mathrm{E}, \mathrm{CIP}, \mathrm{GEN}, \mathrm{CD}, \mathrm{CZ}, \mathrm{FOX}$ & fib & V & 59 & 59 \\
\hline & Amin & Emergency & T, CIP, GEN, CD, CZ, FOX & - & V & 22 & 22 \\
\hline & SB & Emergency & T, E, CIP, GEN, CD, CZ, FOX & eno & V & 398 & 291 \\
\hline Brain abscess & $A Z^{c}$ & ICU & $T, E, C I P, G E N, C D, F O X$ & eno, ebp, fib, fnbB & V & 8 & 343 \\
\hline Respiratory infection & $A Z$ & ICU & E, FOX & $f i b$ & V & 22 & 22 \\
\hline
\end{tabular}

${ }^{a}$ Imam Musa Kazem hospital; ${ }^{b}$ Shahid Beheshti; ${ }^{c}$ Al Zahra; ${ }^{d}$ Sequence type

*CIP ciprofloxacin, CD clindamycin, CZ cefazolin, E erythromycin, FOX cefoxitin, GEN gentamicin, LZD linezolid, $T$ tetracycline, TS trimethoprim sulfamethoxazole

correlation was obtained between MRSA and MSSA strains regarding eno, cna and fib genes $(P<0.001)$.

\section{Multilocus sequence typing (MLST)}

MLST analysis revealed 11 sequence types among MRSA isolates. The results of the MLST were as follows: ST239-SCCmec type III (2 isolates), ST239-SCCmec type II (2 isolates), ST291-SCCmec type V (2 isolates), ST291-SCCmec type II (1 isolates), ST22-SCCmec type II (1 isolate), ST22-SCCmec type V (4 isolates), ST861SCCmec type III (1 isolate), ST 889 -SCCmec type II (1 isolate), ST8-SCCmec type V (1 isolate), ST59-SCCmec type V (3 isolates), ST343-SCCmec type V (1 isolate), ST772-SCCmec type V (1 isolate), ST6-SCCmec type V (1 isolate) and ST1465-SCCmec type V (3 isolates). Also seven MLST- based clonal complexes (CCs) were identified among MRSA strains including: CC8 (41.7\%), CC7 (4.2\%), CC398 (12.5\%), CC59 (12.5\%), CC22 (20.7\%), CC1 (4.2\%) and CC5 (4.2\%) (Table 3).

\section{Discussion}

Nowadays, different clones of antibiotic-resistant strains, such as the MRSA strains, are spreading between healthcare centers and the community [13]. This issue is one of the major challenges of health care systems in the world [13]. The goal of this study was to determine the diversity of common clones, prevalence of virulence genes and antibiotic susceptibility patterns of MRSA strains in four University Teaching Hospitals in the center of Iran. It has been documented that MRSA clones are changing, and CA-MRSA are expanding into healthcare settings [23]. According to different previous studies, SCCmec types I-III and IV-V are commonly responsible for HA-MRSA and CA-MRSA infections, respectively [24]. In the present study, in contrast SCCmec type V was the most prevalent SCCmec type identified among our clinical isolates of MRSA. However recent studies conducted in Armenia and Iran, SCCmec types $\mathrm{V}$ and IV were the most types that identified among MRSA isolates from hospitals respectively [13, 
25] Also in a study by Hallin et al. [26] in Belgium, most clinical MRSA strains belonged to SCCmec types IV. These results could confirm the rotation of clones between community and hospital. In MLST analysis of 24 MRSA isolates, 11 sequence types were identified and among them the ST22 and ST239 were most prevalent. All our MRSA strains with sequence type ST22 were isolated from hospitals in the city of Isfahan, and majority of them, belonged to SCCmec type V expect one isolate which was ST22-SCCmec type II. These MRSA ST22 types contained limited MSCRAMMs genes, although two isolates from burn wound and eye infection demonstrated multi-drug resistant (MDR) phenotype. In a study conducted by Goudarzi et al. [24] in the city of Tehran, ST22 has been documented as the third most commonly detected MRSA clone though the mentioned strains belonged to ST22-SCCmec IV in comparison to our MRSA ST22 which was ST22-SCCmec V. These findings highlight the importance of using several typing methods simultaneously to achieve better analysis. In previous studies of MRSA and MSSA strains in the cities of Isfahan and Tehran the majority of MRSA isolates belonged to ST239 [25]. The high prevalence of ST239 has been documented from many Asian countries especially India, Pakistan, Vietnam, Thailand, Taiwan, China, Sri Lanka, and Singapore [27]. In accordance with other studies, our MRSA isolates with ST239 belonged to SCCmec types II and III, with similar antimicrobial resistance and virulence patterns [22]. Another interesting founding was that these MRSA strains have been isolated from diverse clinical samples in different hospitals in Isfahan Province indicating circulation of these ST clones in clinical settings of our regains. During the time of current study, the third most commonly identified genotypes were ST59-SCCmec V, ST291-SCCmec V and ST1465-SCCmec V. The association of ST291 with HAMRSA has been reported from Iran [28], and ST59 has been identified among both HA- MRSA and CA- MRSA strains in China [29]. Also ST59- SCCmec V has been documented as the predominant CA- MRSA strains in Asia [30]. However, ST1465, ST861, ST 889 and ST772 are reported for the first time in Iran in the present study. Our identified ST types belonged to seven clonal complexes, from which CC8 was the most predominant clone with MDR phenotype and was found in all the studied hospitals. The second most common clonal complex in the present study was CC22 which was not identified in Shahid Beheshti hospital in Kashan. According to MLST genotyping, S. aureus strains have been documented to be highly clonal and the most of the strains belong to a limited number of closely related genotypes. Literature have shown that CC8 (Iberian clone, Brazilian clone, Archaic clone), CC5 (New York/ Japanese clone, Pediatric clone) and CC22 (epidemic
MRSA-15) belong to epidemic MRSA (EMRSA) clones with global distribution in hospitals [27]. In accordance with our study, CC8-V was found as predominant clone in study conducted in Armenia [13]. Also genotyping methods have been showed that $\mathrm{CC} 22$ as the dominant clone are among major clones circulating in Tehran, Iran [21]. ST22 strains which are related to CC22 were determined as the predominant CA-MRSA clone in central of Iran [31]. Furthermore, the ST22 clone has previously been documented as a predominant CAMRSA clone in Germany [32]. The increasing prevalence of the ST22 clone among HA-MRSA strains in recent studies represents that these strains may have been transferred from community to hospitals. Another interesting finding was that, of the new ST groups of MRSA found in current study, ST1465, ST861, and ST889, belonged to CC8. Among them, ST1465 and ST889 were isolated from eye infections and burn wounds in the cities of Isfahan and Kashan that indicates these clones are rotating in hospitals in our region. It is noteworthy that the mentioned strains had a limited number of MSCRAMMs genes studied (eno, fib) and none of these genes were found in one strain with ST1465. However, further studied is needed to give a precise information about the virulence of these strains. In addition the MRSA- ST861 strain was one of the most virulent strains studied, carrying four MSCR AMMs determinants including eno, cna, fib, fnbB. Since all of these strains had a MDR phenotype, they should be carefully considered. Finally, the MRSA-ST772 strain belonged to $\mathrm{CC} 1$, and found to carry eno, cna, $e b p$, and fib genes.

Our results confirmed that majority $(83.3 \%)$ of the MRSA isolates harbored genes of binding factors and the prevalence of eno and fib genes encoding binding proteins was high. The high prevalence of adhesive protein genes in MRSA isolates indicates the persistence of these strains after colonization and subsequent infection. From the point of view of MSCRAMMs genes and correlation with ST groups, the most virulent strains of our MRSA isolates were belonged to $\mathrm{CC} 8, \mathrm{CC} 1$, and CC398. The eno and fib genes were present in all seven identified clonal complexes, whereas the cna was detected in the $\mathrm{CC} 1, \mathrm{CC} 7, \mathrm{CC} 8, \mathrm{CC} 59$, and the $e b p$ gene identified in the CC1, CC5, CC8, and CC398. The fnbB gene, encoding fibronectin binding protein $\mathrm{B}$ was detected in only two clonal complexes including CC8 and CC398. However, all isolates that carried the $f n b B$ gene were identified as the most virulent strains with multiple resistance phenotypes and isolated from various hospitals and important clinical samples including blood and brain abscess. In other studies, all of the $S$. aureus isolates from the bloodstream have been showed to carry the $f n b$ gene [3]. Since CC8 is the most dominant clone 
in our region, the presence of the mentioned virulence genes in this clone is of great importance.

\section{Conclusion}

According to MLST and SCCmec typing results, a relatively high diversity was found in MRSA genotypes in the hospitals of Kashan and Isfahan, and seven clonal complexes were identified. However, it should be considered that only a limited number of isolates were genotyped during current study. Pandemic MRSA clones including $\mathrm{CC} 8$ and $\mathrm{CC} 22$ were the most prevalent clones and the novel ST types including ST1465, ST861, ST 889 and ST772 are reported in the present study for the first time in Iran. Furthermore, presence of momentous sequence types including ST22-SCCmec type II, ST239SCCmec types II and III and ST291-SCCmec type II among important clinical samples such as burn wound and blood due to the risk of further spread of these global multi-antibiotic resistant strains is noteworthy. In addition the high prevalence of MSCRAMMs genes in MRSA isolates demonstrates the high potential of these strains for pathogenicity.

\section{Acknowledgements}

The technical assistance of the staff of Microbiology Laboratory, of the Department of Microbiology and Immunology, School of Medicine, Kashan University of Medical Sciences are gratefully acknowledged. The results described in this paper formed part of a M.Sc. student thesis.

\section{Authors' contributions}

All authors' listed in this research article have been involved and contribute for this study. FF designed the study, collected and analyzed the data, drafted the paper, and supervised the overall work. MO contributed on the data collection and statistical analysis. FF, MO, MS and HS performed the lab works. FF, MS, and MZ analyzed the dataset. Manuscript was prepared by FF, $\mathrm{MO}$, and $\mathrm{MZ}$. All authors read and approved the final manuscript.

\section{Funding}

Nil.

\section{Availability of data and materials}

The data analyzed during the study will be available from the corresponding authors upon request.

\section{Ethics approval and consent to participate}

The purpose and procedures of the study were explained to all participants, and a written informed consent was obtained from all of them. The study was approved by the ethical clearance committees of the Kashan University of Medical Sciences. (IR.KAUMS.REC.1396.003)

\section{Consent for publication}

Not applicable.

\section{Competing interests}

The authors declare that they have no competing interests.

\section{Author details}

${ }^{1}$ Department of Microbiology, School of Medicine, Kashan University of Medical Sciences, Kashan, Iran. ${ }^{2}$ Department of Microbiology, School of Medicine, Alborz University of Medical Sciences, Karaj, Iran. ${ }^{3}$ Dietary Supplements and Probiotic Research Center, Alborz University of Medical Sciences, Karaj, Iran. ${ }^{4}$ Evidence-based Phytotherapy \& Complementary Medicine Research Center, Alborz University of Medical Sciences, Karaj, Iran.
${ }^{5}$ Department of Parasitology and Mycology, School of Medicine, Alborz University of Medical Sciences, Karaj, Iran.

Received: 16 February 2020 Accepted: 9 July 2020

Published online: 17 July 2020

\section{References}

1. Omidi M, Firoozeh F, Saffari M, Sedaghat H, Zibaei M, Khaledi A. Ability of biofilm production and molecular analysis of spa and ica genes among clinical isolates of methicillin-resistant Staphylococcus aureus. BMC Res Notes. 2020;13:19.

2. Walsh EJ, Miajlovic H, Gorkun OV, Foster TJ. Identification of the Staphylococcus aureus MSCRAMM clumping factor B (ClfB) binding site in the aC-domain of human fibrinogen. Microbiology. 2008;154:550-8.

3. Ghasemian A, Peerayeh SN, Bakhshi B, Mirzaee M. The microbial surface components recognizing adhesive matrix molecules (MSCRAMMs) genes among clinical isolates of Staphylococcus aureus from hospitalized children. Iran J Pathol. 2015;10:258-64.

4. Kot B, Sytykiewicz H, Sprawka I. Expression of the biofilm-associated genes in methicillin-resistant Staphylococcus aureus in biofilm and planktonic conditions. Int J Mol Sci. 2018;19:E3487.

5. Joh D, Wann ER, Kreikemeyer B, Speziale $P$, Höök M. Role of fibronectinbinding MSCRAMMs in bacterial adherence and entry into mammalian cells. Matrix Biol. 1999:18:211-23.

6. Tristan A, Ying L, Bes M, Etienne J, Vandenesch F, Lina G. Use of multiplex PCR to identify Staphylococcus aureus adhesins involved in human hematogenous infections. J Clin Microbiol. 2003:41:4465-7.

7. Francois P, Pittet D, Bento M, Pepey B, Vaudaux P, Lew D, et al. Rapid detection of methicillin-resistant Staphylococcus aureus directly from sterile or nonsterile clinical samples by a new molecular assay. J Clin Microbiol. 2003:41:254-60.

8. Kwon NH, Park KT, Moon JS, Jung WK, Kim SH, Kim JM, et al. Staphylococcal cassette chromosome mec (SCCmec) characterization and molecular analysis for methicillin-resistant Staphylococcus aureus and novel SCCmec subtype IVg isolated from bovine milk in Korea. J Antimicrob Chemother. 2005;56: 624-32.

9. Singh SK, Anwar S, Sharma HK, Chaudhary U, Verma SK. FemA gene in Indian isolates of methicillin resistant Staphylococcus aureus-isolation and amplification through real time PCR. Eur J Exp Biol. 2014;4:90-4.

10. Huang CC, Ho CM, Chen HC, Li CY, Tien N, Fan HM, et al. Evaluation of double locus ( $C l f B$ and spa) sequence typing for studying molecular epidemiology of methicillin-resistant Staphylococcus aureus in Taiwan. J Microbiol Immunol Infect. 2017;50:604-12.

11. Green SM, Marsh P, Ahmad N, Jefferies JM, Clarke SC. Characterization of community and hospital Staphylococcus aureus isolates in Southampton, UK. J Med Microbiol. 2010;59:1084-8.

12. Lee $C Y$, Fang YP, Chang YF, Wu TH, Yang YY, Huang YC. Comparison of molecular epidemiology of bloodstream methicillin-resistant Staphylococcus aureus isolates between a new and an old hospital in Central Taiwan. Int J Infect Dis. 2019;79:162-8.

13. Mkrtchyan HV, Xu Z, Yacoub M, Ter-Stepanyan MM, Karapetyan HD, Kearns $\mathrm{AM}$, et al. Detection of diverse genotypes of methicillin-resistant Staphylococcus aureus from hospital personnel and the environment in Armenia. Antimicrob Resist Infect Control. 2017;6:19.

14. Mahon CR, Lehman DC, Manuselis G. Textbook of diagnostic microbiology. $5^{\text {th }}$ ed. Washington DC: Saunders; 2015.

15. Amiri A, Firoozeh F, Moniri R, Zibaei M. Prevalence of CTX-M-Type and PER extended-spectrum $\beta$-lactamases among Klebsiella spp. isolated from clinical specimens in the teaching hospital of Kashan, Iran. Iran Red Crescent Med J. 2016;18:e22260

16. Clinical and Laboratory Standards Institute. erformance Standards for Antimicrobial Susceptibility Testing. $29^{\text {th }}$ information supplement. Wayne PA: M100-S27: 2019.

17. Jukes L, Mikhail J, Bome-Mannathoko N, Hadfield SJ, Harris LG, El-Bouri K, Davies AP, Mack D. Rapid differentiation of Staphylococcus aureus, Staphylococcus epidermidis and other coagulase-negative staphylococci and meticillin susceptibility testing directly from growth-positive blood cultures by multiplex real-time PCR. J Med Microbiol. 2010;59:1456-61.

18. Boye K, Bartels MD, Andersen IS, Møller JA, Westh H. A new multiplex PCR for easy screening of methicillin-resistant Staphylococcus aureus SCCmec types I-V. Clin Microbiol Infect. 2007;13:725-7. 
19. Ito T, Kuwahara-Arai K, Katayama Y, Uehara Y, Han X, Kondo Y, et al. Staphylococcal cassette chromosome mec (SCCmec) analysis of MRSA. Methods Mol Biol. 2014;1085:131-48.

20. Pourmand MR, Hassanzadeh S, Mashhadi R, Askari E. Comparison of four diagnostic methods for detection of methicillin resistant Staphylococcus aureus. Iran J Microbiol. 2014;6:341-4.

21. Goudarzi M, Goudarzi H, Sá Figueiredo AM, Udo EE, Fazeli M, Asadzadeh M, et al. Molecular characterization of methicillin resistant Staphylococcus aureus strains isolated from intensive care units in Iran: ST22-SCCmec IV/t790 emerges as the major clone. PLoS One. 2016;11:e0155529.

22. D'Souza N, Rodriques C, Mehta A. Molecular characterization of methicillinresistant Staphylococcus aureus with emergence of epidemic clones of sequence type (ST) 22 and ST 772 in Mumbai, India. J Clin Microbiol. 2010; 48:1806-11.

23. Ghanbari F, Saberianpour S, Zarkesh-Esfahani F, Ghanbari N, Taraghian A Khademi F. Staphylococcal cassette chromosome mec (SCCmec) typing of methicillin-resistant Staphylococcus aureus strains isolated from communityand hospital-acquired infections. Avicenna J Clin Microb Infec. 2017;4: e42244.

24. Goudarzi M, Eslami G, Rezaee R, Heidary M, Khoshnood S, Sajadi NR. Clonal dissemination of Staphylococcus aureus isolates causing nosocomial infections, Tehran, Iran. Iran J Basic Med Sci. 2019:22:238-45.

25. Havaei SA, Halaji M, Vidovic S, Dillon JR, Karbalaei M, Ghanbari F, et al. Prevalence and genotyping of methicillin-resistant and - susceptible Staphylococcus aureus strains isolated from patients in a university hospital, Isfahan, Iran. Jundishapur J Microbiol. 2017;10:e13571

26. Hallin M, Denis O, Deplano A, De Mendonça R, De Ryck R, Rottiers S, et al. Genetic relatedness between methicillin-susceptible and methicillin-resistant Staphylococcus aureus: results of a national survey. J Antimicrob Chemother. 2007;59:465-72.

27. Zafar A, Stone M, Ibrahim S, Parveen Z, Hasan Z, Khan E, et al. Prevalent genotypes of meticillin-resistant Staphylococcus aureus: report from Pakistan. J Med Microbiol. 2011;60:56-62.

28. Sedaghat H, Esfahani BN, Halaji M, Jazi AS, Mobasherizadeh S, Havaei SR, et al. Genetic diversity of Staphylococcus aureus strains from a teaching hospital in Isfahan, Iran: the emergence of MRSA ST639- SCCmec III and ST343- SCCmec III. Iran J Microbiol. 2018;10:82-9.

29. Peng H, Liu D, Ma Y, Gao W. Comparison of community- and healthcareassociated methicillin-resistant Staphylococcus aureus isolates at a Chinese tertiary hospital, 2012-2017. Sci Rep. 2018;8:17916.

30. Noguchi N, Nakaminami H, Nishijima S, Kurokawa I, So H, Sasatsu M. Antimicrobial agent of susceptibilities and antiseptic resistance gene distribution among methicillin-resistant Staphylococcus aureus isolates from patients with impetigo and staphylococcal scalded skin syndrome. J Clin Microbiol. 2006;44:2119-25.

31. Japoni-Nejad A, Rezazadeh M, Kazemian H, Fardmousavi N, van Belkum A Ghaznavi-Rad E. Molecular characterization of the first community-acquired methicillin-resistant Staphylococcus aureus strains from Central Iran. Int J Infect Dis. 2013;17:e949-54.

32. Linde $H$, Wagenlehner F, Strommenger B, Drubel I, Tanzer J, Reischl U, et al. Healthcare-associated outbreaks and community-acquired infections due to MRSA carrying the Panton-valentine leucocidin gene in southeastern Germany. Eur J Clin Microbiol Infect Dis. 2005;24:419-22.

\section{Publisher's Note}

Springer Nature remains neutral with regard to jurisdictional claims in published maps and institutional affiliations.

Ready to submit your research? Choose BMC and benefit from:

- fast, convenient online submission

- thorough peer review by experienced researchers in your field

- rapid publication on acceptance

- support for research data, including large and complex data types

- gold Open Access which fosters wider collaboration and increased citations

- maximum visibility for your research: over $100 \mathrm{M}$ website views per year

At BMC, research is always in progress.

Learn more biomedcentral.com/submissions 